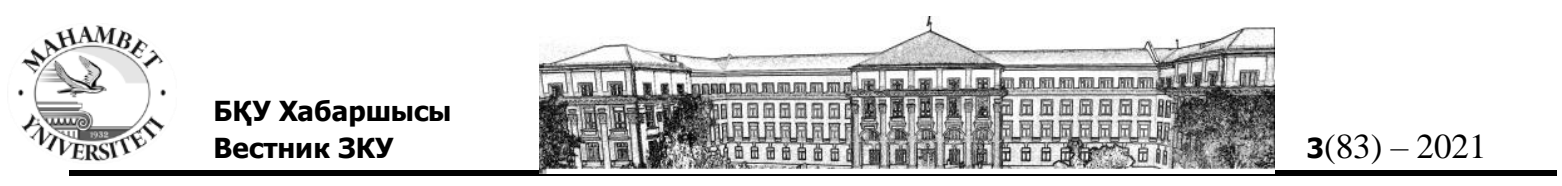

UDC 561.23

IRSTI 34.35 .00

DOI 10.37238/1680-0761.2021.83(3).22

\author{
${ }^{1}$ Kabaeva S. M.*, ${ }^{2}$ Kurmekesh A. D. \\ 1,2 Makhambet Utemisov West Kazakhstan University, \\ Uralsk, Kazakhstan \\ *Correspondence: Kabaeva.s.m@ mail.ru
}

E-mail: Kabaeva.s.m@mail.ru

\title{
ABSORPTION OF ATMOSPHERIC NITROGEN BY TUBEROUS
}

Annotation. Tuber bacteria are usually found in tubers in the roots of legumes, and some species are found separately in the soil. When tuberous bacteria live selectively with plants, they provide them with nitrogenous nutrients and feed on corneal compounds that are released from the roots of plants themselves. At the same time, some of the nitrogen is used by the bacteria themselves. The absorption of nitrogen in the roots of legumes depends on the phase of plant development. Tuberous bacteria are involved in enriching the soil with nitrogen. It creates conditions for inorganic substances to undergo changes in the composition of the soil, that is, to interfere.

Keywords: microorganisms; atmosphere; sterilized; tuber bacteria; azotobacteria; nitrogen absorption; legumes.

\section{Introduction}

In nitrogen-deficient soils, legumes grow well. The scientist M. S. Voronin (1865) studied tubers in the roots of legumes and found out that microorganisms live there. Further, scientists Gel Rigel and Wilfart suggested that there are tubers in the roots of legumes, and these tubers absorb atmospheric nitrogen in the air. This is proven by experience. In 1888, for the first time, these bacteria were isolated by Beyering in its pure form and BACT. "they called it radicola. Recent studies have shown that tuberous bacteria go through a certain cycle during their development. At a young age, they become like Spore-free, mobile sticks, and as they become adults, their fibers are destroyed and vacuoles begin to form in their cells. Branching of sticks is also possible. It is called bacteriodes. Bacteriodes are crushed, become spherical, and then become stick-like cells again. Tuberous bacteria are usually found in legumes.

In order to absorb atmospheric nitrogen, tuber bacteria need Copperhead compounds. These compounds include various sugars: glucose, levuleza, raffinose, maltose, and galactose. In addition, they can use alcohol and organic substances. The specified organic substances are corroded by the tuber and absorbed atmospheric nitrogen during this process. Tuber bacteria have their own forms, which are typical for different legume families [2].

All of them can mainly be divided into six groups:

1.tuberous bacteria of legumes, beef alfalfa, legumes, lentils and chickpeas.

2.Tuberouslobia bacteria.

3. Soy tuberous bacteria.

4.tuberous bacteria of Clover and alfalfa. These include Clover, camel clover, and Trigonella tuber bacteria.

5.chickpea tuber bacteria. This includes not only chickpeas, but also tuberous bacteria of the legume plant mash and arachis. 


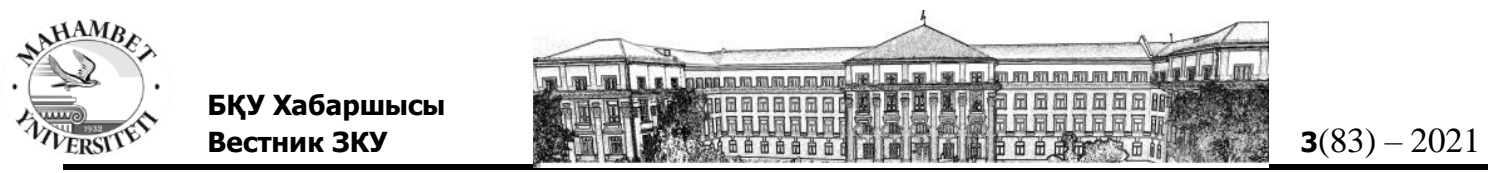

6.chickpea tuber bacteria.

This classification of tuberous bacteria was obtained according to the systems of L. M. Dorosinsky. These include legumes and their tuberous bacteria, which are distributed only in our country.

In addition, a number of tuberous bacteria survive very intensively and slow down the life process of other species. Such poorly developed species are widely distributed in the soil. When used in practice, it is not allowed to infect the roots of legumes of such species [3, 360 P].

In addition, we have already mentioned that each legume family has its own specific tuber bacteria. According to this, tuber bacteria give good results only when used. In addition, in nature there are also microbes that absorb small amounts of nitrogen, which are bound in the form of a small mixture of ammonia. They are called aminonitrophil bacteria. They are able to absorb a small amount of nitrogen in the gas State [3, $360 \mathrm{p}]$.

About a hundred years ago, Science discovered tuberous bacteria that absorb atmospheric nitrogen from the roots of plants that do not belong to the legume family. They were found in herbaceous, Woody and shrubby vegetation. It is proved that the total number of plants containing tuberous bacteria exceeds about two hundred.

It is not easy to separate and study the microorganisms in the tuber. However, the materials obtained showed that actinomycetes, which absorb nitrogen at the roots of Woody and shrubby plants, and various bacteria in herbaceous plants. When examined by a special method, it turned out that actinomycetes from the roots of woody plants belong to representatives of the genus Frankia. Currently, micro-organisms belonging to the genus Franka have settled in the roots. 17 relatives of Woody and indoor shrubby plants are known. In the leaves of some plants, tuberous bacteria are found. It turns out that they can absorb molecular nitrogen. It is recommended to use nitrogen-rich leaves of such plants as fertilizers $[4,140$ p.].

But for plants, it is not the amount of elements that matters, but the forms in the soil that are convenient for the plant to absorb. Total reserves of nutrients in the plowed horizon of chernozem, per 1 ha according to N. P. Remezv in 1952. What amount of elements can provide the average yield of wheat $[4,140 \mathrm{p}]$.

Organic impurities of phosphorus and phosphorus content most minerals are not absorbed by plants. The main mass of potassium in the soil is contained in the secondary dispersion silicate (hydroside), in this state it cannot be digested by plants. Plants spread the absorbed potassium and water-soluble mixtures of potassium throughout, the content of which in the soil is insignificant. Calcium and magnesium are also absorbed and only in water-soluble form, useful for plants, nitrogen in the air is not absorbed, microorganisms undergo changes under the influence of azotobacters.

In addition to nitrogenous substances, atmospheric nitrogen can also be absorbed by fatty acid bacteria. S. N. Vinogradsky identified and studied one of its species in its pure form in 1893. This bacterium lives in anaerobic conditions, its shape is rod-shaped. During the formation of spores, one end is rounded like a drumstickNitrogenous tuber bacteria are shown in the figure below[4, 140 p]. (Figure - 1)

Nodule bacteria

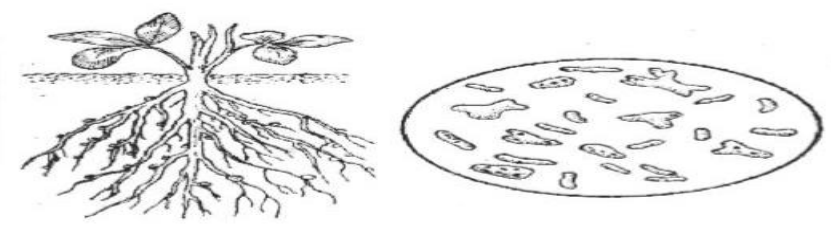

Image of tuber bacteria (Fig. - 1, 140 p.) 
Common in nature, fatty acid causes the fermentation process. During life, the atmosphere absorbs nitrogen. Because they are adapted to live where there is no oxygen, they co-exist with a number of aerobic saprophyte microbes. It absorbs nitrogen very strongly, especially during spore formation. Spores consist of a mucous membrane that protects them from adverse environmental conditions. The energy needed to absorb atmospheric nitrogen is derived from the fatty acid discovery process. It absorbs between 10 and 12 milligrams of molecular nitrogen when fermenting each gram of sugar. This process occurs when there is little nitrogen in the nutrient medium. On the contrary, when there are enough ammonia salts, the molecules do not absorb nitrogen well. The importance of this microbe in nature is great. In soils where there are no azotobacters, this Clostridium Pasteurianum is found [4, $140 \mathrm{p}]$.

Poor in nitrogen, legumes grow well in general. The scientist M. S. Voronin (1865) studied tubers in the roots of legumes and found out that microorganisms live there. Further, scientists Gel Rigel and Wilfart suggested that there are tubers in the roots of legumes, and these tubers absorb atmospheric nitrogen in the air.

This classification of tuberous bacteria was obtained according to the systems of L. M. Dorosinsky. These include legumes and their tuberous bacteria, which are distributed only in our country.

\section{Research materials and methods}

In addition, a number of tuberous bacteria survive very intensively and slow down the life process of other species. Such poorly developed species are widely distributed in the soil. When used in practice, it is not allowed to infect the roots of legumes of such species. For this purpose, a study was carried out using soil samples (Fig. - 2) [5, 100 p].
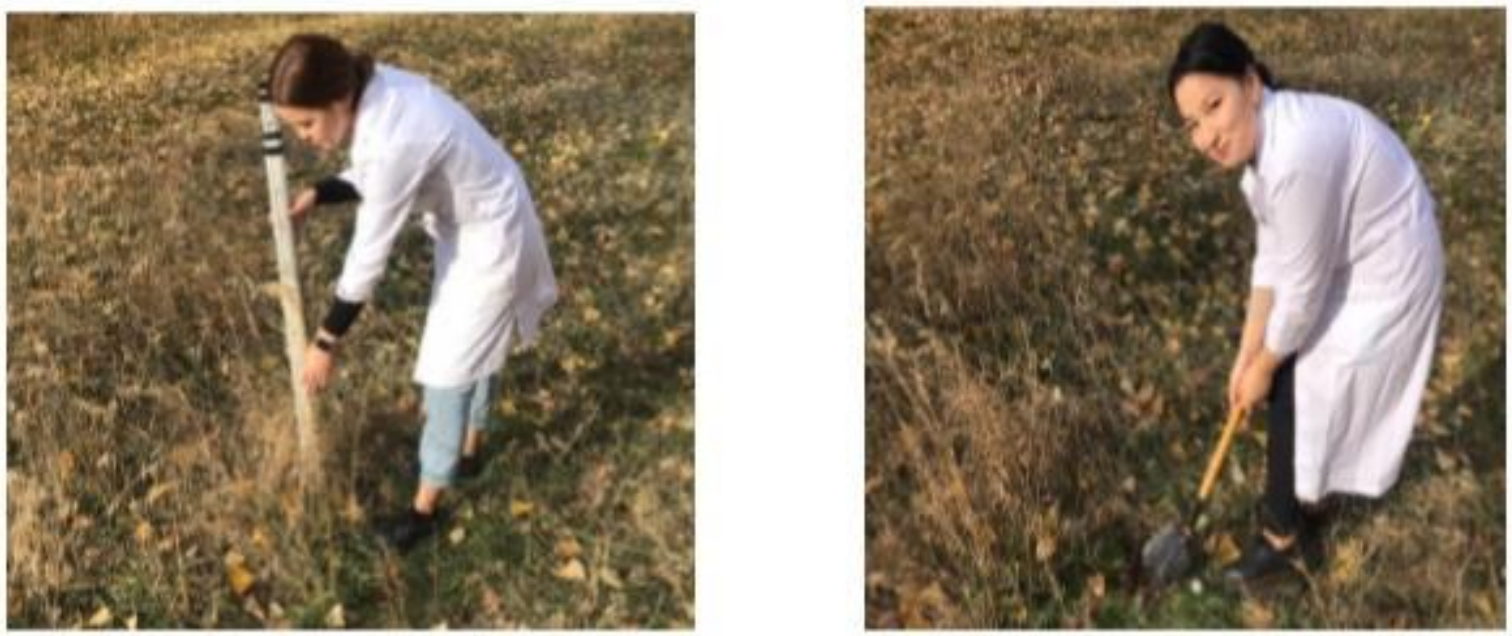

Appearance during soil sampling (Fig. - 2)

In agriculture, grass sowing is one of the most powerful mechanisms that raise the culture of Agriculture. It will connect Crop Production, Animal Husbandry, and beekeeping in one complex and strengthen the feed base of livestock. Among the herbs, alfalfa is in particular demand. It is considered a valuable feed in animal husbandry. And its dosage form improves the composition of the soil, providing a large number of nutritious biosates. These and other features of alfalfa contributed to the training within the framework of seminars of the Center for agribusiness NCE RK "Atameken". Classes were held in Karasay district on the basis of IP "Konovalov". Lecturer Valery Lukbanov spoke about how alfalfa farming activates agricultural industries [6]. 


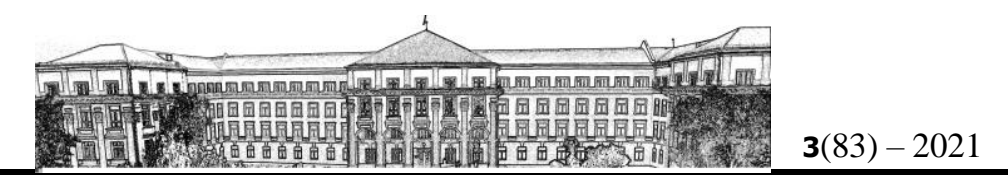

\section{Research results}

"Alfalfa cultivation is a biological factor in the development of agricultural production. It allows you to make full use of the bioclimate, soil, water and energy potential. It increases soil fertility and prevents the development of an erosive process. It also reduces the man-made impact on the soil, minimizes tillage and improves the land subject to man-made loads. The Alfalfa system of Agriculture is involved as a systemic factor in optimizing agricultural production, V. Lukbanov said."

The use of this type of hay simultaneously reduces material costs by $50-70 \%$, increases honey production and forage harvesting by $200-300 \%$, and grain productivity by $20-30 \%$. Planting alfalfa at the grain sowing site solves the problem of winter vegetation, leads to optimal land use, allows you to get 10 centners of grain from 1 hectare and an additional 70-80 centners of dry mass. The use of alfalfa forms the moisture reserves of the product [7].

Also, the participants of the seminar were interested in questions about the influence of herbs and their role in the fight against pests and diseases. Sowing alfalfa dramatically reduces rotting and damage to plants. When alfalfa roots and soil residues decompose, dicumarin is formed in the soil. This, in turn, contributes to the destruction of pests and carriers of diseases [8].

In nitrogen-deficient soils, legumes grow well. The scientist M. S. Voronin (1865) studied tubers in the roots of legumes and found out that microorganisms live there. Further, scientists Gel Rigel and Wilfart suggested that the legumes have tubers in their roots, and these tubers absorb atmospheric nitrogen in the air $[10,11]$.

This classification of tuberous bacteria was obtained according to the systems of L.M.Dorosinsky. These include legumes and their tuberous bacteria, which are distributed only in our country.

\section{Conclusion}

In conclusion, one row of tuber bacteria lives very intensively, slowing down the life process of other species. Such poorly developed species are widely distributed in the soil. When used in practice, it is not allowed to infect the roots of legumes [12, 13, $134 \mathrm{P}-344 \mathrm{P}$.].

Tuberous bacteria are involved in enriching the soil with nitrogen. It creates conditions for inorganic substances in the soil to undergo changes, i.e. interference [14].

\section{Thanks}

Most of the nitrogen in the soil is found only in organic form, so it is not suitable for complex, including cultivated plants. Only mixtures of ammonium and nitrate, which are formed as a result of microbiological life, are absorbed by the plant.

\section{REFERENCES}

[1] Baqtybaev M.S. (2010) Mal azyqtyq pıöpterdı öñdeu jäne mal şaruaşylyğy üşın joğary sapaly azyq // «Ösımdık şaruaşylyğy önımderın saqtau jäne öñdeu tehnologiasy [High-quality feed for processing and animal husbandry] Petropavlovsk: M. Qozybaev atyndağy SQMU [in Kazakh].

[2] Nürğazy Q.Ş. (2012) Ipi qara şaruaşylyğy. Mal şaruaşylyğy [Large black farming. Animal husbandry] Almaty, JŞS RPBK «Däuır» [in Kazakh].

[3] Mojaev N.İ., Ärınov Q.K., Nürğaliev A.N., Mojaev A.N. (2003) Aralas şöpter sebu // Ösımdık şaruaşylyğy [Sowing mixed herbs. Crop production] (Oqulyq) Aqmola, «Jaña Arqa» [in Kazakh].

[4] Baqtybaev M.S. (2009) Ipi qarany azyqtandyru // DÄRISTER KURSY «Mal şaruaşylyğynyñ negızderı» [Fundamentals of animal husbandry] Oqu - ädistemelık qüraly. Petropavl: M.Qozybaev atyndağy SQMU [in Kazakh].

[5] Baqtybaev M.S. (2012) Auylşaruaşylyq maldardy qalypty azyqtandyrudyñ neglzı. Mal

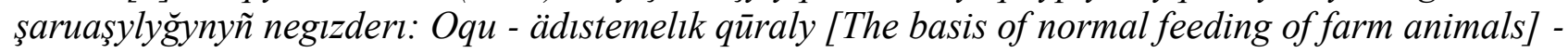
Petropavl: M.Qozybaev atyndağy SQMU [in Kazakh].

[6] Omartqojaūly N.S. (2016) Äbdırahmanov Maldy azyqtandyru jäne suaru//Mal azyqtandyrudy üiymdastyru jäne baqylau: Oqu qūraly. [Feeding and watering of livestock. Organization and control of feeding] - Almaty: Bastau [in Kazakh]. 
[7] Asanov K.A., Velichko P.K., Nikolenko I. A. (2000) Intensivnoe vyrashhivanie ljucerny na oroshenii $v$ Kazahstane // Intensivnye tehnologii vozdelyvanija kormovyh kul'tur: Teorija $i$ praktika [Intensive cultivation of alfalfa on irrigation in Kazakhstan. Intensive technologies of cultivation of fodder crops: Theory and practice] Moscow [in Kazakh].

[8] Abugaliev I.A. et al. (2007) Tehnologia proizvodstva i zagotovka kormov na paşne.[ Production technology and forage harvesting on arable land] Alma-Ata [in Russian]

[9] Sovetov A.V. (2000) O razvedenii trav na poljah [About the cultivation of herbs in the fields] Moscow [in Russian] Russian].

[10] Dmitriev K.D. (2001) Senokosnye ugod'ja i pochvy [Hayfields and soils] Moscow [in

[11] Ajdarov I. P. Aleksashenko A. A. \& Pestov L. F. (2013) Raschety konturov uvlazhnenija pri kapel'nom $i$ vnutripochvennom oroshenii. Teorija $i$ praktika kompleksnogo meliorativnogo regulirovanija [Calculations of humidification contours for drip and subsurface irrigation] Moscow [in Russian].

[12] Shhepetkov N.G. (2013) Nauchnye osnovy vysokoj produktivnosti ovoshhnyh kul'tur: Uchebnoe posobie.[Scientific foundations of high productivity of vegetable crops] - Astana: Kazahskij agrotehnicheskij un-t im. S.Sejfullina [in Russian].

[13] Aliev D. A. (2004) Fotosinteticheskaja dejatel'nost', mineral'noe pitanie $i$ produktivnost' rastenij [Photosynthetic activity, mineral nutrition and plant productivity]. - Baku: Jelm [in Russian].

[14] Amirov B.M. O nauchnom obespechenii ovoshhevodstva Kazahstana Retrieved from http://group-global.org/ru/publication/5851-o-nauchnom-obespecheniiov oshchevodstva-kazahstana [in Russian].

\section{Кабаева С.М., Курмекеш А.Д. \\ ТУЙНЕК БАКТЕРИЯЛАРЫНЫН АТМОСФЕРА АЗОТЫН СIHIPУI}

Андатпа. Түйнек бактерияларының, әдетте, бұршақ тұқымдас өсімдіктердің тамырындағы түйнектерінде, ал кей бір түрлері топырақта жеке күйінде кездеседі. Түйнек бактериялары өсімдіктермен селбесіп тіршілік еткенде, оларды азотты қоректік заттармен қамтамасыз етеді де, өздері өсімдіктердің тамырынан бөлінентін көмертекті қосылыстармен қоректенеді. Сонымен қатар азоттың бір бөлігін бактериялардың өздері пайдаланады. Бұршақ тұқымдас өсімдіктердің тамырындағы азотты сіңіруі өсімдіктің даму фазасына байланысты. Түйнек бактериялары топырақты азотпен байытуға ат салысады. Топырақ құрамындағы бейорганикалық заттардың өзгеріске ұшырауына яғни араласуына жағдай жасайды.

Кілт сөздер: Микроағзалар, атмосфера, зарарсыздандырылған, түйнек бактериялары, азотобактерлер, азотты сіңіру, бұршақ тұқымдас.

\section{Кабаева С.М., Курмекеш А.Д. ПОГЛОЩЕНИЕ АТМОСФЕРНОГО АЗОТА КЛУБНЕВЫМИ БАКТЕРИЯМИ}

Аннотация. Клубневые бактерии обычно встречаются в корневых клубнях бобовых, а некоторые виды обитают в почве изолированно. Когда клубневые бактерии взаимодействуют с растениями, они снабжают их азотными питательными веществами и питаются углеродными соединениями, которые выделяются из корней растений. Кроме того, часть азота используется самими бактериями. Поглощение азота корнями бобовых культур зависит от фазы развития растений. Клубневые бактерии способствуют обогащению почвы азотом. Способствуют преобразованию неорганических веществ в почве.

Ключевые слова: Микроорганизмы, атмосфера, стерильные, клубневые бактерии, азотобактерии, поглощение азота, бобовые. 